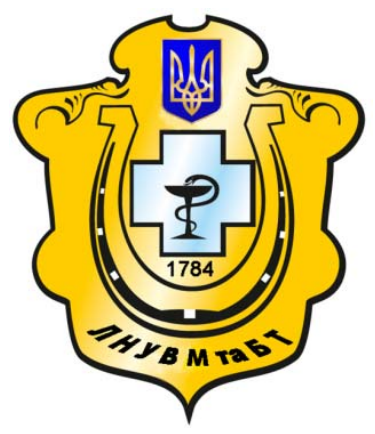

Науковий вісник Львівського національного університету ветеринарної медицини та біотехнологій імені С.3. Гжицького

Scientific Messenger of Lviv National University of Veterinary Medicine and Biotechnologies named after S.Z. Gzhytskyj

doi:10.15421/nvlvet7529

ISSN 2519-268X print

ISSN 2518-1327 online

$\underline{\text { http://nvlvet.com.ua/ }}$

УДК 637.1.075.579.66

\title{
Формування біоплівок на нержавіючій сталі AISI 321, залежно від шорсткості поверхні та початкової кількості E.coli
}

\author{
Х.Ю. Кравченюк, М.Д. Кухтин \\ kravchenukx30@gmail.com
}

Тернопільський національний технічний університет імені Івана Пулюя, вул. Руська, 56, м. Тернопіль, 46001, Укрїна

\begin{abstract}
У статті наведено результати досліджень щодо впливу шорсткості поверхні нержавіючої харчової сталі на процес формування біоплівки штамом Escherichia coli ATCC 25299. Для дослідження були використані пластинки з нержавіючоі корозійно-стійкої нікель-хромової аустенітної сталі марки AISI 321, з шорсткістю поверхні $R_{a}=0,955$ мкм, $R_{a}=0,63$ мкм та $R_{a}=0,16$ мкм. Встановлено, щуо за сприятливих температурних режимів кишкова паличка протягом 9-12 год. здатна формувати біоплівки середньої та високої щільності на поверхні нержавіючої сталі з шорсткістю 0,955 мкм. Проте щільність біоплівок за початкової кількості клітин E. coli до 1 тис. на см² площі була в середньому в 1,8-2,2 раза (P $\leq 0,05)$ нижчою, порівняно з біоплівкою, сформованою у варіантах з початковою кількістю клітин 2-10 тис. та 20-50 тис. на см² площі сталі. Інтенсивність формування біоплівки на поверхні сталі з шорсткістю 0,63 мкм була дещо сповільнена, порівняно з поверхнею із шорсткістю 0,955 мкм. Проте, незважаючи на це, за щільністю біоплівки у варіантах 3 початковою кількістю клітин E. coli 2-10 тис. і 20-50 тис. на см ${ }^{2}$ площі були високої щільності починаючи з 12 години інкубаџії, тобто аналогічно, як на поверхні із шорсткістю 0,955 мкм. Процес плівкоутворення за таких початкових кількостях E. coli на поверхні з шорсткістю 0,63 мкм завершувався на 24 год., тимчасом, як за шорсткості 0,955 мкм на 18 год. інкубачії. За початкової кількості E. соІі на поверхні сталі до 1 тис. з шорсткістю поверхні 0,63 мкм, біоплівки формувалися високої щільнності, починаючи з 20 год., що, в середньому, на 5-6 год. довще, порівняно з шорсткістю поверхні 0,955 мкм.

За шорсткості поверхні сталі 0,16 мкм процес плівкоутворення значно сповільнився, порівняно з поверхнями, які мали шорсткість 0,955 та 0,63 мкм. Через дев'ять годин інкубаиії E. соli на сталі з шорсткістю 0,16 мкм біоплівки були в середньому в 2,0 рази $(P \leq 0,05)$ слабшої шільності, порівняно з шорсткістю 0,955 мкм, i в 1,3-1,6 раза $(P \leq 0,05)$, порівняно 3 шорсткістю 0,63 мкм незалежно від початкової кількості E. coli. 3 a 12 годин інкубації E. coli у варіанті з початковою кількістю до 1 тис. на см² площзі біоплівка ще була слабкою, а у варіантах з початковою кількістю 2-10 тис. і 20-50 тис. на см ${ }^{2}$ площчі - середньої щцільності - 0,805 і 0,916 од. відповідно. Протягом 18 годин інкубації біоплівка була середньої щільності тільки у варіанті з початковою кількістю до 1 тис. E. coli на см² поверхні. За більшої початкової кількості бактерій вона була високої щуільності. Тільки через 24 год інкубації E. coli біоплівки у всіх варіантах були високої щільності.

Ключові слова: мікробна біоплівка, формування, Escherichia coli, щільність, шорсткість, нержавіюча сталь, технологічне обладнання.
\end{abstract}

\section{Формирование биопленок на нержавеющей стали AISI 321, в зависимости от шероховатости поверхности и исходного количества $E . c o l i$}

\author{
Х.Ю. Кравченюк, М.Д. Кухтин \\ kravchenukx30@gmail.com
}

Тернопольский национальный технический университет имени Ивана Пулюя, ул. Русская, 56, г. Тернополь, 46001, Украина

В статье изображены результаты исследований влияния шероховатости поверхности нержавеющей пищевой стали на проиесс формирования биопленки штаммом Escherichia coli ATCC 25299. Для исследования были использованы пластинки из

\section{Citation:}

Kravchenyuk, K.U., Kuchtyn, M.D. (2017). Biofilms formation on the stainless steel AISI 321 surface in terms of surface roughness and E.coli initial number. Scientific Messenger LNUVMBT named after S.Z. Gzhytskyj, 19(75), 144-148. 
нержавеюшей коррозионно-стойкой никель-хромовой аустенитной стали марки AISI 321, с шероховатостью поверхности Ra $=0,955$ мкм, Ra =0,63 мкм и Ra =0,16 мкм. Установлено, что при благоприятных температурных режимов кишечная палочка в течение 9-12 ч способна формировать биопленки средней и высокой плотности на поверхности нержавеющей стали с шероховатостью 0,955 мкм. Однако плотность биопленок при начальной количества клеток E. софі до 1 тьс. в см плоцади была в среднем в 1,8-2,2 раза $(P \leq 0,05)$ ниже по сравнению с биопленкой сложившейся в вариантах с начальной количеством клеток 210 тыс. и 20-50 тыс. в см² плошади стали. Интенсивность формирования биопленки на поверхности стали с иероховатостью 0,63 мкм была несколько замедленная, по сравнению с поверхностью с шероховатостью 0,955 мкм. Однако, несмотря на это по плотности, биопленки в вариантах с начальной количеством клеток E. coli 2-10 тыс. И 20-50 тыс. В см ${ }^{2}$ площуади были высокой плотности начиная с 12 часа инкубации, так же, как на поверхности с шероховатостью 0,955 мкм. Прочесс пленкообразования при таких начальных количествах E. coli на поверхности с шероховатостью 0,63 мкм завершался на 24 ч., в то время же время, как по шероховатости 0,955 мкм на 18 часу инкубачии. В количестве Е. соІі на поверхности стали до 1 mыс. с шероховатостью поверхности 0,63 мкм, биопленки формировались высокой плотности начиная с 20 ч., что в среднем на 5-6 ч дольше по сравнению с шероховатостью поверхности 0,955 мкм.

По шероховатости поверхности стали 0,16 мкм прочесс пленкообразования значительно замедлился по сравнению с поверхностями, которые имели шероховатость 0,955 и 0,63 мкм. Через 9 ч. инкубации Е. соІі на стали с шероховатостью 0,16 мкм биопленки были в среднем в 2,0 раза $(P \leq 0,05)$ слабее плотности по сравнению с шероховатостью 0,955 мкм и, в 1,3-1,6 раза $(P \leq 0,05)$ по сравнению с иероховатостью 0,63 мкм независимо от исходного количества Е. солі. 3 а 12 часов инкубации E. coli в варианте с начальной численностью до 1 тыс. в см ${ }^{2}$ площади биопленка ещзе была слабой, а в вариантах с начальной количеством 2-10 тыс. и 20-50 тыс. в см ${ }^{2}$ площуади - средней плотности - 0,805 и 0,916 ед. соответственно. В течение 18 часов инкубации биопленка была средней плотности только в варианте с начальным количеством до 1 тыс. E. coli на см² поверхности. Только через 24 часа инкубации E. соli биопленки во всех вариантах были высокой плотности.

Ключевые слова: микробная биопленка, формирование, Escherichia coli, плотность, шероховатость, нержавеющая сталь, технологическое оборудование.

\title{
Biofilms formation on the stainless steel AISI 321 surface in terms of surface roughness and $E$.coli initial number
}

\author{
K.U. Kravchenyuk, M.D. Kuchtyn \\ kravchenukx30@gmail.com \\ Ternopil Ivan Puluj National Technical University, \\ Ruska Str., 56, Ternopil, 46001, Ukraine
}

\begin{abstract}
The results of the research of stainless food steel surface roughness impact on biofilm Escherichia coli formation have been given. The stainless plates AISI 321 of surface roughness $R_{a}=0.955 \mathrm{mkm}, R_{a}=0.63 \mathrm{mkm}$ and $R_{a}=0.16 \mathrm{mkm}$ were used in the research. It was found that at favorable temperatures bacterium coli is able to form biofilms of medium and high density on the stainless steel surface of roughness $0.955 \mathrm{mkm}$ during 9-12 hours. Though, biofilms density at initial E. coli number up to 1000 per $\mathrm{cm}^{2}$ of area was on the average 1.8-2.2 times $(P \leq 0.05)$ lower in comparison with the biofilm formed in cases with initial cell number 200010000 and 20000-50000 on $\mathrm{cm}^{2}$ of stainless steel surface.

Biofilm formation intensity on the steel of roughness $0.63 \mathrm{mkm}$ surface was rather decelerated comparing to the surface of roughness $0.955 \mathrm{mkm}$. Nevertheless, as for density the biofilms in cases with initial E. coli number 2000-10 000 and 20000-50000 on $\mathrm{cm}^{2}$ of surface were of high density from 12 hours of incubation, i.e. the same as in case with the surface of roughness $0.955 \mathrm{mkm}$. Film forming process at such initial E. coli number on the surface of roughness $0,63 \mathrm{mkm}$ was completed at the $24^{\text {th }}$ hour while on the surface of roughness $0.955 \mathrm{mkm}$ - at the $18^{\text {th }}$ hour of incubation.

For the steel of roughness $0,16 \mathrm{mkm}$ the film forming process was greatly decelerated comparing to the surfaces of roughness 0.955 and $0.63 \mathrm{mkm}$. After 9 hours of E. coli incubation on the steel of roughness $0.16 \mathrm{mkm}$ the biofilms were on the average 2,0 times $(P \leq 0.05)$ lower density in comparison with roughness $0,955 \mathrm{mkm}$ and $1.3-1.6$ times $(P \leq 0.05)$ lower comparing to roughness $0,63 \mathrm{mkm}$ irrespective of the initial E. coli number. After 12 hours of E. coli incubation in case with initial number up to 1000 per $\mathrm{cm}^{2}$ of area the biofilm was still weak, and in cases with initial number 2000-10000 and 20000-50000 on $\mathrm{cm}^{2}$ of surface-of medium density - 0.805 and 0.916 units correspondingly. Only after 24 hours of E. coli incubation the biofilms in all cases were of high
\end{abstract} density.

Key words: microbial biofilm, formation, Essherishia coli, density, roughness, stainless steel, processing equipment.

\section{Вступ}

Забруднення мікроорганізмами технологічного обладнання в харчовій промисловості $є$ важливою проблемою, оскільки негативно впливає на якість і безпечність сировини та готових продуктів харчування. Адже понад 40\% харчових отруєнь людей у світі спричиняються мікроорганізмами, які надходять у сировину та готові продукти 3 технологічного устаткування (Haeghebaert et al, 2001). Це пов'язано з тим, що мікроорганізми виживають на технологічному устаткуванні завдяки специфічній властивості - здат- ності формувати біоплівки (Pe'rez-Rodri'guez et al, 2008; Lequette et al, 2010). Біоплівка - це жива сукупність одного або декількох видів чи родів бактерій, яка постійно оновлюється, прикріплена до біогенної чи абіогенної поверхні та оточена полісахаридним матриксом (Costerton et al, 2003). Дезінфікуючі засоби не завжди діють на бактерії, які сформовані у біоплівки, адже резистентність бактерій у біоплівках до дезінфікуючих речовин, антибіотиків чи антисептиків приблизно в 100 разів більша, ніж у планктонних мікроорганізмів (Levis, 2001; Kukhtyn, 2011). Це пов'язано з тим, що в біоплівках мікроорганізми пе- 
ребувають в метаболічно інертних формах, на які погано діють біоциди, а також через те, що пори і канали біоплівок не пропускають великі молекули біоцидів всередину біоплівки.

Основним моментом, без якого неможливе утворення біоплівки, є процес адгезії мікроорганізмів до поверхні, доступної для подальшої колонізації. Адгезія мікроорганізмів залежить від доволі великої кількості змінних чинників, особливо таких, як рід та вид мікроорганізму, шорсткість поверхні, гідрофільність чи гідрофобність матеріалу та ряду екологічних факторів (осмолярність, $\mathrm{pH}$, температура, парціальний тиск кисню, наявність антибактеріальних речовин і т. д.). У молочній промисловості шорсткість поверхні нержавіючої сталі не повинна перевищувати $\mathrm{R}_{\mathrm{a}}=0,8$ мкм (EHEDG, 2004) і вважається, чим вона менша, тим буде більш гігієнічна. Проте в процесі експлуатації поверхня нержавіючої сталі зазнає змін і на ній з'являються потертості, подряпини, які збільшують шорсткість і тим самим площу контакту з мікроорганізмами.

Метою роботи було дослідити вплив шорсткості поверхні нержавіючої харчової сталі марки AISI 321 на процес формування біоплівки Escherichia coli.

\section{Матеріал і методи дослідження}

Дослідження процесу формування біоплівки проводили на моделі штаму Escherichia coli ATCC 25299. Для дослідження були використані пластинки з нержавіючої корозійно-стійкої нікель-хромової аустенітної сталі марки AISI 321, розміром $30 \times 30$ мм та товщиною 5 мм, 3 шорсткістю поверхні $\mathrm{R}_{\mathrm{a}}=0,955$ мкм, $\mathrm{R}_{\mathrm{a}}=0,63$ мкм та $\mathrm{R}_{\mathrm{a}}=0,16$ мкм.

3 метою визначення впливу шорсткості поверхні нержавіючої сталі на процес формування біоплівки E. coli, дослідження поділили на три варіанти. У пер- шому варіанті в стерильні чашки Петрі ставили стерильні пластини 3 нержавіючої сталі 3 відповідною шорсткістю поверхні та вносили в чашку МПБ з концентрацією E. coli, щоб на 1 см$^{2}$ площі пластини припадало в середньому до 1 тис. клітин. У другому варіанті у чашки Петрі 3 пластинами нержавіючої сталі вносили МПБ з концентрацією E. coli від 2 тис. до 10 тис. клітин на $1 \mathrm{~cm}^{2}$ площі. У третьому варіанті у чашки Петрі з пластинами нержавіючої сталі вносили МПБ з концентрацією E. coli від 20 тис. до 50 тис. клітин на $1 \mathrm{~cm}^{2}$ площі. Через 3, 6, 9, 12, 18 та 24 годин інкубації за температури $37^{\circ} \mathrm{C}$ пластини витягували 3 чашок Петрі, триразово відмивали від планктонних (неприкріплених) мікроорганізмів фосфатним буфером та фіксували утворені біоплівки E.coli $96^{\circ}$ етиловим спиртом. Після фіксування біоплівки фарбували, у $0,1 \%$ розчині кристалічного фіолетового. Потім кожну пластинку окремо заливали $7,0 \mathrm{~cm}^{3} 96^{\circ}$ етиловим спиртом та залишали на 10 хв. Після експозиції 10 хв. відбирали $5 \mathrm{~cm}^{3}$ промивного розчину з біоплівок та визначали його оптичну густину спектрофотометрично за довжини хвилі 570 нМ.

За оптичної густини промивного розчину до 0,5 од. щільність сформованих біоплівок вважали низькою, від 0,5 до 1,0 од. - середньою та при густині розчину понад 1,0 од. щільність сформованих біоплівок вважали високою.

Шорсткість поверхонь пластин нержавіючої сталі визначали за допомогою профілометра марки 296, згідно з ГОСТ 2789-73 (GOST 2789-73, 1973).

\section{Результати та їх обговорення}

Результати досліджень формування біоплівки на нержавіючій сталі марки AISI 321 з шорсткістю поверхні 0,955 мкм, залежно від початкової кількості клітин E. coli, протягом 24 годин наведено на рис. 1.

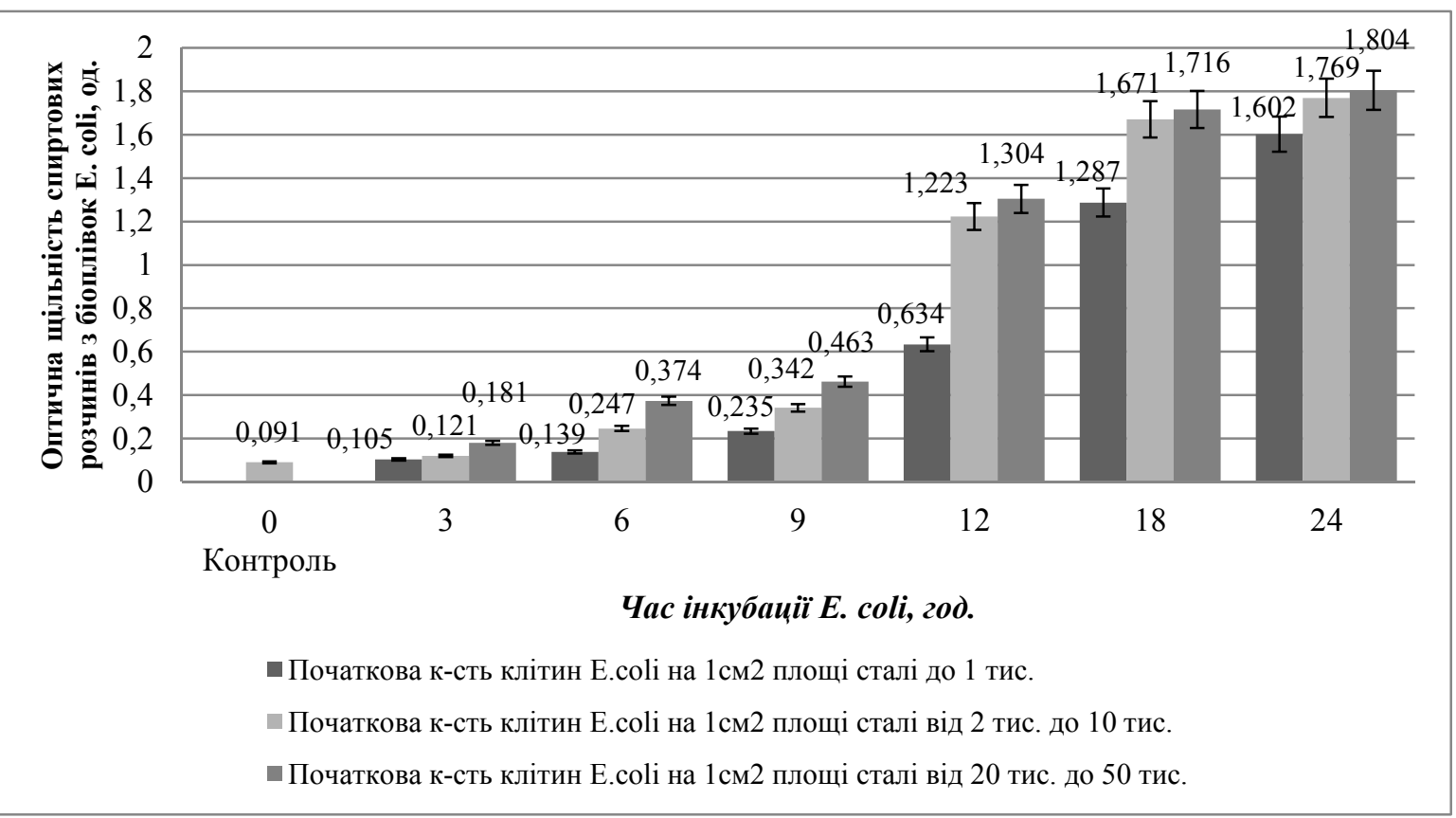

Рис. 1. Формування біоплівки E. coli на нержавіючій сталі марки AISI 321 шорсткістю $\mathbf{R}_{\mathrm{a}}=0,955$ мкм при температурі $37^{\circ} \mathrm{C}$ 
3 рис. 1 видно, що за температури $37^{\circ} \mathrm{C}$ упродовж трьох годин інкубації $E$. coli щільність біоплівок, залежала від початкової кількості мікробних клітин на поверхні нержавіючої сталі. Так, за початкової кількості E. coli на поверхні до 1 тис./ $/ \mathrm{cm}^{2}$ площі через три години щільність біоплівки була практично також як у контролі. Водночас за початкової кількості $E$. coli від 2 до 10 тис./ $\mathrm{cm}^{2}$ площі, щільність біоплівки зросла в 1,3 раза $(\mathrm{P} \leq 0,05)$, а за початкової кількості $E$. coli від 20 до 50 тис. в 2,0 рази $(\mathrm{P} \leq 0,05)$. Надалі упродовж наступних годин інкубації біоплівка у всіх варіантах ставала щільніша, однак протягом 9 годин вирощування вона ще була слабкою до 0,5 од. Після дев'ятої години інкубації відмічаємо інтенсивний процес плівкоутворення і на 12 годину у варіантах 3 початковою кількістю клітин $E$. coli від 2 до 10 тис. та $2-50$ тис./ $/ \mathrm{cm}^{2}$ площі біоплівка ставала високої щільності $-1,22$ та 1,30 од відповідно. У варіанті до 1 тис. клітин на см² площі сталі вона була середньої щільності - 0,63 од.
На 18 годину інкубації E. coli на поверхні сталі 3 шорсткістю 0,955 мкм процес плівкоутворення практично завершився у варіантах 3 початковою кількістю клітин E. coli від 2 до 50 тис. на см² площі, а у варіанті до 1 тис. клітин біоплівка стала високої щільності 1,28 од. У цьому варіанті процес плівкоутворення завершився на 24 годині, тобто щільність біоплівок зрівнялася, як у варіантах два та три.

Отже, проведені дослідження вказують на те, що за сприятливих температурних режимів кишкова паличка протягом 9-12 год здатна формувати біоплівки середньої та високої щільності на поверхні нержавіючої сталі з шорсткістю 0,955 мкм. Проте щільність біоплівок за початкової кількості клітин $E$. coli до 1 тис. на $\mathrm{cm}^{2}$ площі була в середньому в 1,8-2,2 раза $(\mathrm{P} \leq 0,05)$ нижчою, порівняно з біоплівкою сформованою у варіантах 3 початковою кількістю клітин 210 тис. та $20-50$ тис. на см ${ }^{2}$ площі сталі.

На рис. 2 наведено дані щодо формування біоплівки E. coli на поверхні нержавіючої сталі з шорсткістю $\mathrm{R}_{\mathrm{a}}=0,63$ мКм.

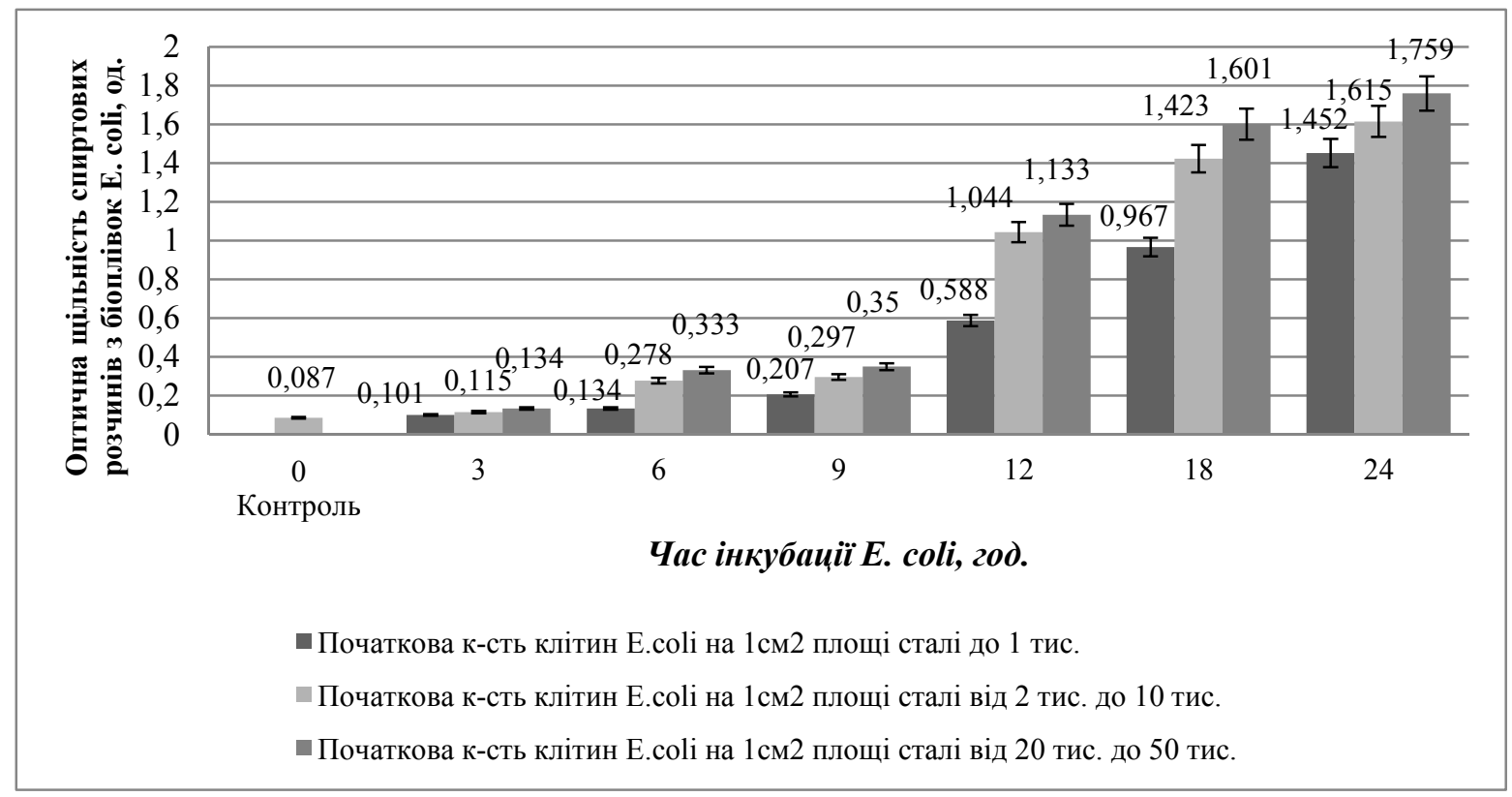

Рис. 2. Формування біоплівки $E$. coli на нержавіючій сталі марки AISI 321 шорсткістю $\mathrm{R}_{\mathrm{a}}=0,63$ мкм при температурі $37^{\circ} \mathrm{C}$

Як видно з даних рис. 2, інтенсивність формування біоплівки на поверхні сталі з шорсткістю 0,63 мкм, була дещо сповільнена, порівняно 3 поверхнею із шорсткістю 0,955 мкм. Проте незважаючи на це, за щільністю біоплівки у варіантах 3 початковою кількістю клітин E. coli 2-10 тис. і 20-50 тис. на см² площі були високої щільності починаючи з 12 годин інкубації, тобто аналогічно, як на поверхні із шорсткістю 0,955 мкм. Процес плівкоутворення за таких початкових кількостях E. coli на поверхні з шорсткістю 0,63 мкм завершувався на 24 годині, тимчасом, як за шорсткості 0,955 мкм на 18 годині інкубації. За початкової кількості E. coli на поверхні сталі до 1 тис. 3 шорсткістю поверхні 0,63 мкм, біоплівки формувалися високої щільності, починаючи з 20 години, що, в середньому, на 5-6 год довше, порівняно 3 шорсткістю поверхні 0,955 мкм.
На рисунку 3 наведено дані щодо формування біоплівки E. coli на поверхні сталі з шорсткістю 0,16 мкм. Дані рис. 3 вказують на те, за що за шорсткості поверхні сталі 0,16 мкм процес плівкоутворення значно сповільнився, порівняно $з$ поверхнями, які мали шорсткість 0,955 та 0,63 мкм. Через дев'ять годин інкубації E. coli на сталі з шорсткістю 0,16 мкм біоплівки були в середньому в 2,0 рази $(\mathrm{P} \leq 0,05)$ слабшої щільності, порівняно з шорсткістю 0,955 мкм $\mathrm{i}$, в $1,3-1,6$ раза $(\mathrm{P} \leq 0,05)$, порівняно $з$ шорсткістю 0,63 мкм незалежно від початкової кількості $E$. coli.

За 12 год. інкубації $E$. coli у варіанті $з$ початковою кількістю до 1 тис. на $\mathrm{cm}^{2}$ площі біоплівка ще була слабкою, а у варіантах з початковою кількістю 210 тис. і 20-50 тис. на см² площі - середньої щільності $-0,805$ і 0,916 од. відповідно. 


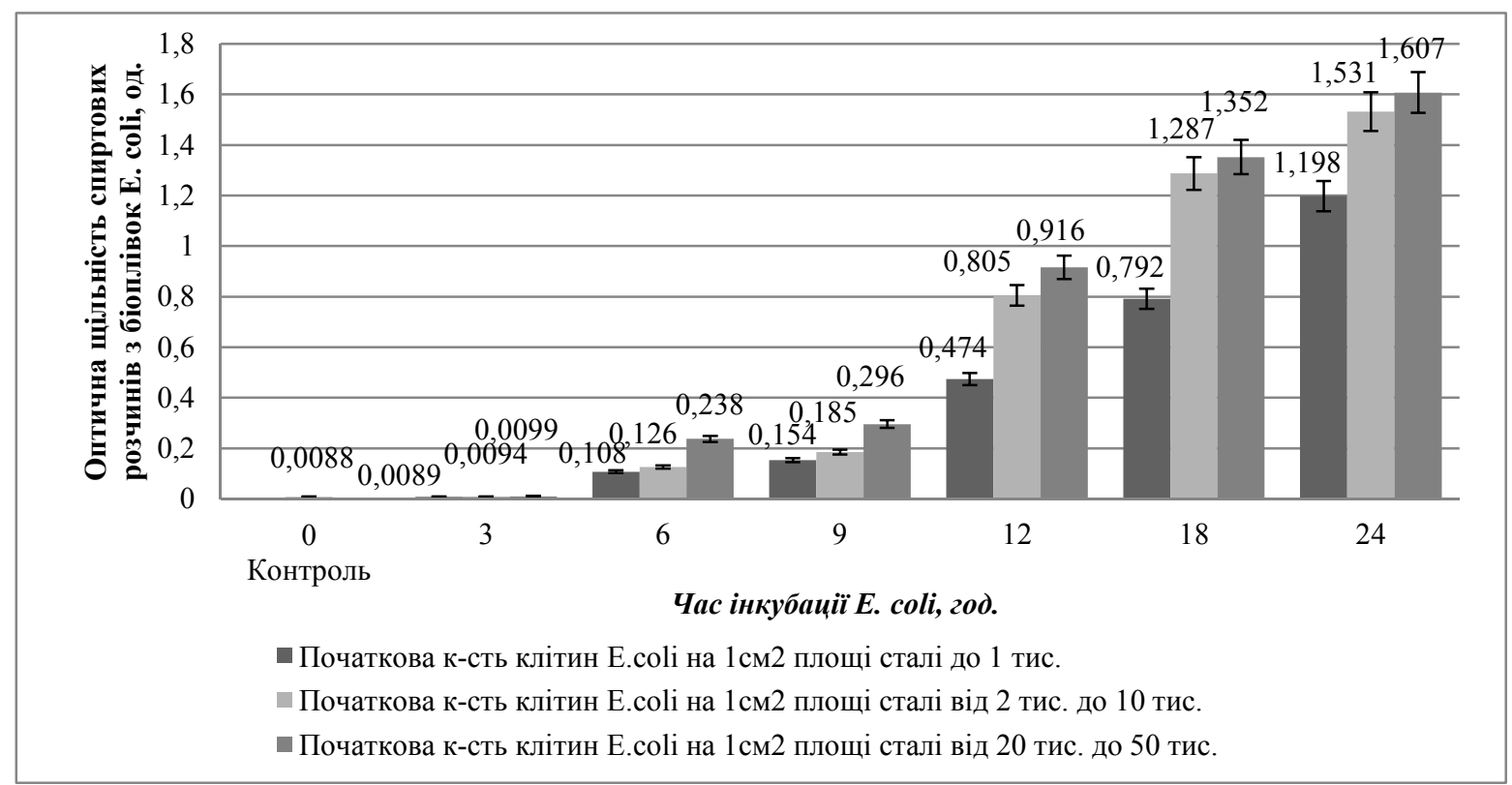

Рис. 3. Формування біоплівки $E$. coli на нержавіючій сталі марки AISI 321 шорсткістю $\mathrm{R}_{\mathrm{a}}=0,16$ мкм при температурі $37^{\circ} \mathrm{C}$

Протягом 18 годин інкубації біоплівка була середньої щільності тільки у варіанті з початковою кількістю до 1 тис. E. coli на см² поверхні. За більшої початкової кількості бактерій вона була високої щільності. Тільки через 24 год. інкубації E. coli біоплівки у всіх варіантах були високої щільності.

Отже, підсумок проведених досліджень, можна відзначити, що на процес формування мікробних біоплівок на харчовій сталі марки AISI 321 впливає шорсткість поверхні та початкова кількість бактерій. Тобто результати вказують, що на поверхні $з$ шорсткістю 0,16 мкм процес адгезії E. coli проходить повільніше, порівняно зі сталлю, яка мала шорсткість 0,63 i 0,955 мкм. Крім того, отримані дані вказують, що для запобігання формуванню біоплівок високої щільності необхідно проводити ретельну санітарну обробку поверхні сталевого обладнання з метою недопускання великої кількості бактерій на ньому.

\section{Висновки}

Процес формування біоплівки E. coli на поверхні нікель-хромової аустенітної сталі марки AISI 321 залежав, як від шорсткості поверхні, так і від початкової кількості мікробних клітин на сталі.

За початкової кількості E. coli на поверхні сталі до 1 тис. 3 шорсткістю поверхні 0,63 мкм біоплівки формувалися високої щільності, починаючи з 20 год, що, в середньому на 5-6 год довше, порівняно з шорсткістю поверхні 0,955 мкм і на 10 год довше, порівняно 3 шорсткістю поверхні 0,16 мкм.

Через дев'ять годин інкубації E. coli на сталі з шорсткістю 0,16 мкм біоплівки були в середньому в 2,0 рази слабшої щільності, порівняно 3 шорсткістю 0,955 мкм i в 1,3-1,6, порівняно 3 шорсткістю 0,63 мкм незалежно від початкової кількості E. coli.

Перспективи подальших досліджень полягають у розробці математичної моделі формування біоплівок на поверхні нержавіючої сталі з різною шорсткістю, залежно від виду мікроорганізмів, їх морфології, початкової кількості, температури навколишнього середовища, 3 метою прогнозування і запобігання утворення біоплівок на технологічному обладнані в харчовій промисловості.

\section{Бібліографічні посилання}

Haeghebaert, S., Le Querrec, F., Vaillant, V. (2001). Food poisoning incidents in France in 1998. Bull Epidemiol Hebdomad. 65-70.

Lequette, Y., Boels, G., Clarisse, M. (2010). Christine Faille Using enzymes to remove biofilms of bacterial isolates sampled in the food-industry. Biofouling. 26(4), 421-431.

Pe'rez-Rodri'guez, F., Valero, A., Carrasco, E. (2008). Understanding and modelling bacterial transfer to foods: a review. Trends Food Sci. Technol, 131-144.

Costerton, J.W., Veeh, R., Shirtliff, M. (2003). The application of biofilm science to the study and control of chronic bacterial infections. J. Clin. Invest. 112(10), 1466-1477.

Levis, K. (2001). Riddle of Biofilm Resistance. Antimicrobical Agents and Chemotherapy. 45(4), 999-1007.

Kukhtyn, M.D. (2011) Theoretical substantiation of veterinary-sanitary regulations and development of control system of whole cooled milk production: abstract of doctoral (Veterinary science) dissertation. Lviv, 40 (in Ukrainian).

Hygienic equipment design criteria (Guideline Document No. 8), Brussels: EHEDG 2004. ENEDG.

GOST 2789-73 (1973). Surface roughness. Parameters and characteristics. Moscow: GosStandard USSR. 6 (in Russian).

Стаття надійшла до редакиії 24.02.2017 